Speak out or stay silent? | 50

ADRIAN GONZALEZ'

\title{
Speak out or stay silent? A study of oil company-community relations through the political ecology of voice ${ }^{2}$
}

"[T]o try to lift the pipeline, we had to immerse in that water without any protection ... under the instruction of engineers, they told us that we had to try to reach it, so we did immerse there without any clothing, only underwear and it was full of crude oil, it was thick" (A Cuninico indigenous resident in the Peruvian Amazon describes their 2014 oil spill remediation work).

This powerful opening testimony, corroborated by other residents to me in the summer of 2015, highlights one of the many challenges that natural resource extraction poses, particularly in the Global South. A wide array of scholarship has shown that Global South resource rich countries are hindered by weak institutions (Mehlum et al., 2006), an absence of strong governance (Doro and Kufakurinani, 2018) and endemic corruption (Gonzalez, 2016a). This 'natural resource curse' (Natural Resource Governance Institute, 2015) has not only led to lower levels of economic development (Adams et al., 2019), but also resulted in far higher levels of social conflict and environmental pollution (Byakagaba et al., 2019). Research in subSaharan African (Lundgren et al., 2013; Obida et al., 2017; Amnesty International, 2018) and Latin American (Bebbington and Bebbington, 2011; Flemmer and Schilling-Vacaflor, 2015; Bebbington and Bury, 2018) contexts typify these developmental challenges.

In these difficult national environments, the local interaction between resource extractive companies and local people is difficult. The absence of state civil

\footnotetext{
' ADRIAN GonZALEZ is a Lecturer in Human Geography / Planning (Environmental) at the School of Geography and Planning, Cardiff University.

${ }^{2}$ This article was originally published in http://www.alternautas.net/blog/2020/10/23/speak-outor-stay-silent-a-study-of-oil-company-community-relations-through-the-political-ecology-ofvoice
} 
development such as educational and medical facilities and transport infrastructure, can leave communities dependent on the support of extractive industries through corporate social responsibility (CSR) initiatives (Gonzalez, 2016b). This dependency (Taarup-Esbensen, 2019), often exacerbated by the important local economic role that extractive industries play, can in turn increase the likelihood of societal division and possibly conflict (Aaron and Patrick, 2013). It also highlights the unequal power relations between extractive industries and local communities (Kemp and Owen, 2013) and the struggle which societal groups can face in holding economic actors accountable for mismanagement issues such as pollution.

Efforts to counteract these harmful effects have seen an attempt to improve extractive company and community engagement practices within different international standards (Wilson et al., 2016). To that end, the Organisation for Economic Cooperation and Development (OECD) has developed the concept of "meaningful stakeholder engagement." This can be defined as:

"ongoing engagement with stakeholders that is two-way [sharing opinions and perspectives and listening to different viewpoints to reach mutual understanding], conducted in good faith [active and honest participation to find common ground], responsive [companies appropriately addressing adverse issues like environmental pollution through timely remedial action] and ongoing [continuing throughout the lifecycle of a project]" (OECD, 2015 p.9).

This concept is evident from several policy mechanisms which can be used by extractive companies and also the state to proactively engage with local people. These include local communities actively managing biodiversity or natural resources through community monitoring programmes (Costa et al., 2018), a mechanism which can improve sustainability in conservation efforts (Holck, 2007) and generate empowered participation in decision-making (Constantino et al., 2012). Further mechanisms that strengthen participation and inclusion include prior consultation and the ability of citizens to provide free, prior and informed consent to local development projects (Barrera-Hernández, 2016). Extractive company respect for, and adoption of free, prior and informed consent, can conceivably reduce the likelihood of social conflict and reputational damage (Hanna and Vanclay, 2013).

This article, based on recently published PhD research (Gonzalez, 2018a), aims to explore the reality of meaningful participation, specifically the ability of local citizens to report environmental pollution incidents. It will start by setting out the political ecology of voice (PEV) theoretical framework developed for the $\mathrm{PhD}$ research 
Speak out or stay silent? | 52

(Gonzalez, 2015) and the methodology and case study information, before summarising the research findings and what they tell us about meaningful participation, voice, accountability and power.

\section{Exit, voice and political ecology; establishing the PEV theoretical framework}

In 2013, I commenced a PhD in Human Geography with the aim of exploring why certain Global South oil producing countries suffer from such high levels of environmental pollution in comparison to other Global North producers. I focused my research on an investigation into the ability and willingness of local people to report environmental pollution issues via a case study of Peru's Loreto Region. The study was conducted through the development of my PEV theoretical framework, which integrates the voice theory of the twentieth century political economist, Albert Hirschman, with political ecology.

Albert Hirschman was one of the twentieth century's most influential economists who authored numerous texts into development economics and political theory. The initial foray of my $\mathrm{PhD}$ research into consumer accountability of business led me to examine Hirschman's theories of exit and voice which were outlined in his 1970 book Exit, Voice and Loyalty: Responses to Decline in Firms, Organisations and States. According to Hirschman, consumers are faced with two possible actions when responding to declining standards caused by business or states. The first is to exit, whereby consumers stop buying a firm's products or members leave an organisation (Hirschman, 1970). It is described as an impersonal, indirect, silent, private decision (Hirschman 1970; 1995). The second action is voice, where consumers or organisation members as individuals or collective groups, vocally express dissatisfaction to mobilise wider public opinion (Hirschman, 1970). Broadly, it is a public, messy action due to the different gradients that encompass it; from faint grumbling to violent protest. Voice is an active action, though it can occur silently e.g. muted remarks (Zuindeau, 2009), through horizontal and vertical situations such as speaking with one's peers, and conversations with higher level actors such as REI managers (Ravnborg and Gomez, 2015; O'Donnell, 1986). Hirschman considered exit to be closely interlinked with economics and voice with politics and public action, though this was not exclusive (Hirschman 1970; 1981; 1982; 1992).

Hirschman's exit and voice theories have been widely contextually analysed, e.g. on media citizenship see Ramana (2013), highlighting their usefulness as evaluative tools 
(Picciotto, 2015), but never within an environmental pollutant scenario. It became clear to me that there was scope for this to occur, particularly surrounding voice. In situations where public interest (Hirschman, 1982) or public happiness is affected, such as a food hazard, automobile safety problem (Hirschman, 1981), or as PEV contends, an environmental issue (Gonzalez, 2015), vocalisation is more relevant as people are motivated to defend their quality of life. People's strong group loyalty (Hirschman, 1970) and livelihood attachments (Groves, 2015) such as employment or family connections are also key drivers of vocalisation. This is particularly true when one considers time horizons, in which it is unlikely for people to exit without first vocalising their concerns, indicating that exit is often an action of last resort or one pursued by the wealthy (Hirschman, 1978) or those with weaker livelihood attachments. For Hirschman's voice theory to be successfully reconceptualised into an environmental context, it was necessary for it to be integrated into a framework that could provide relevant contextual and analytical parameters. Political ecology became a clear choice.

The wide array of approaches and contributions to the field make any attempt at defining political ecology difficult (Greenberg and Park 1994; Ingalls and Stedman, 2016). Nevertheless, at a broad level, this interdisciplinary framework seeks to understand the relationship between society and nature and the causes of socioenvironmental inequality and injustice (Bryant, 2015; Ingalls and Stedman, 2016). Within political ecology, there are several important aspects that provide a degree of coherence and which are also important for reconceptualising Hirschman's ideas in this environmental scenario.

The first is its focus on politics and therefore power relations which play a fundamental role within the framework (Ahlborg and Nightingale, 2018). Political ecologists highlight the struggle for access and control of resources between actors operating at different scales and in different spaces (Bebbington, 2012; Spiegel, 2017; Gehab and Suhardiman, 2019). The link between politics/power and scale and space make the latter important features of the field. Scale is seen as an ongoing process of societal conflict through which environmental, social and political change is politicised (Harriss and Alatout, 2010). Meanwhile, political ecology research into specific localities such as peri-urban (Karpouzoglou et al., 2018) or frontiers (Willow and Wylie, 2014) show how they can be used by powerful actors to regulate and control areas of land or resources (Clapp, 2004). Lastly, political ecology acknowledges that the causes of socio-environmental issues operate in a temporally 
dynamic environment. In other words, these 'moments in temporal trajectories' (Mathevet et al., 2015 p.2) change over time. Political ecology and these four underlying elements, power, scale, space and time, provide important analytical detail and help to contextualise Hirschman's voice theory in this environmental pollutant scenario.

PEV can be defined as the study of a specific political, economic, social and geographical environment in which different stakeholders e.g. citizens, communitybased organisations and non-governmental organisations, utilise their voice over an environmental issue (Gonzalez, 2015). Consequently, voice can be understood as an active expression of protestation against disagreeable issues (Gonzalez, 2018b) and can occur in several ways. There is individual voice, in which a person seeks to enact change solely through this act. There is also collective voice, which in the context of environmental issues is most often used. This is not only because environmental issues affect a varying number of people, but also that engagement with vertical voice actors like the state or extractive companies is best achieved collectively in order to try and mitigate hostility from the state or other actors (Okonta and Douglas, 2001; Barrett, 2014). One must also reflect on who is vocalising and their multiple voices present within the environmental management sphere. There is individual or citizen voice and institutional voice stemming from actors such as extractive companies or the government. The third is collective voice, including community-based organisations such as religious or student movements, trade union and nongovernmental organisations. So, while actor has a different voice, they are interconnected and have a predominant impact on citizen voice, how it is heard and by whom (Gonzalez, 2015).

The articulation of voice is affected by the specific environment in which different actors are situated. This contextual environment has been illustrated in Figure 1 below. This includes the political environment and whether a country is democratic or authoritarian which influences the "freedom of voice" (Gonzalez, 2018b). As Hirschman himself evaluated, it is easier to participate in a public protest when one only loses time through the act of participation than when one thereby risks losing one's head' (1982, pp.4-5). PEV must also investigate the impact that socioeconomic and ethnic influences have on voice. Studies indicate that active participation is easier for middle-class and high earners, who can more easily afford the participatory costs (money, time and effort) than low-income households (Crisp 
et al., 2016). Marginalised citizens will also struggle to be heard or have their voices recognised by vertical voice actors (Saffari, 2016).

Space, scale, accessibility and development are also important to consider. Socioeconomic issues are more acute for rurally located citizens, where access to vertical voice structures e.g. government representatives, is more challenging and virtual connectivity is often poor or non-existent (Gonzalez, 2019). PEV research must also reflect on non-state actors' interactions and impacts with citizens. Each company will have their own access and dialogue arrangements with local people which may see them seek to quash societal concerns via 'special favours' (Hirschman, 1981 p.241) such as improved CSR projects (Hoelscher and Rustad, 2019) or utilise repressive reprisals against local groups (White et al., 2018). Meanwhile, community-based and non-governmental organisations can help strengthen and empower citizens through capacity building initiatives (Ulleberg, 2009), mobilise local communities (Vijayakumar, 2018) and scale up their political voice (Perreault, 2003) to achieve different objectives such as environmental justice. Conversely, these actors also risk dispossessing local people of their voice, whose ideas and concerns can become lost in this wider movement and its aims (Cook et al., 2017), an issue exacerbated by the weakness that citizens have in forcing downward accountability of these actors (Andrews, 2018). Lastly, PEV acknowledges that these contextual influences on voice occur in a temporally fluid environment and at different scales and spaces (Gonzalez, 2015). 


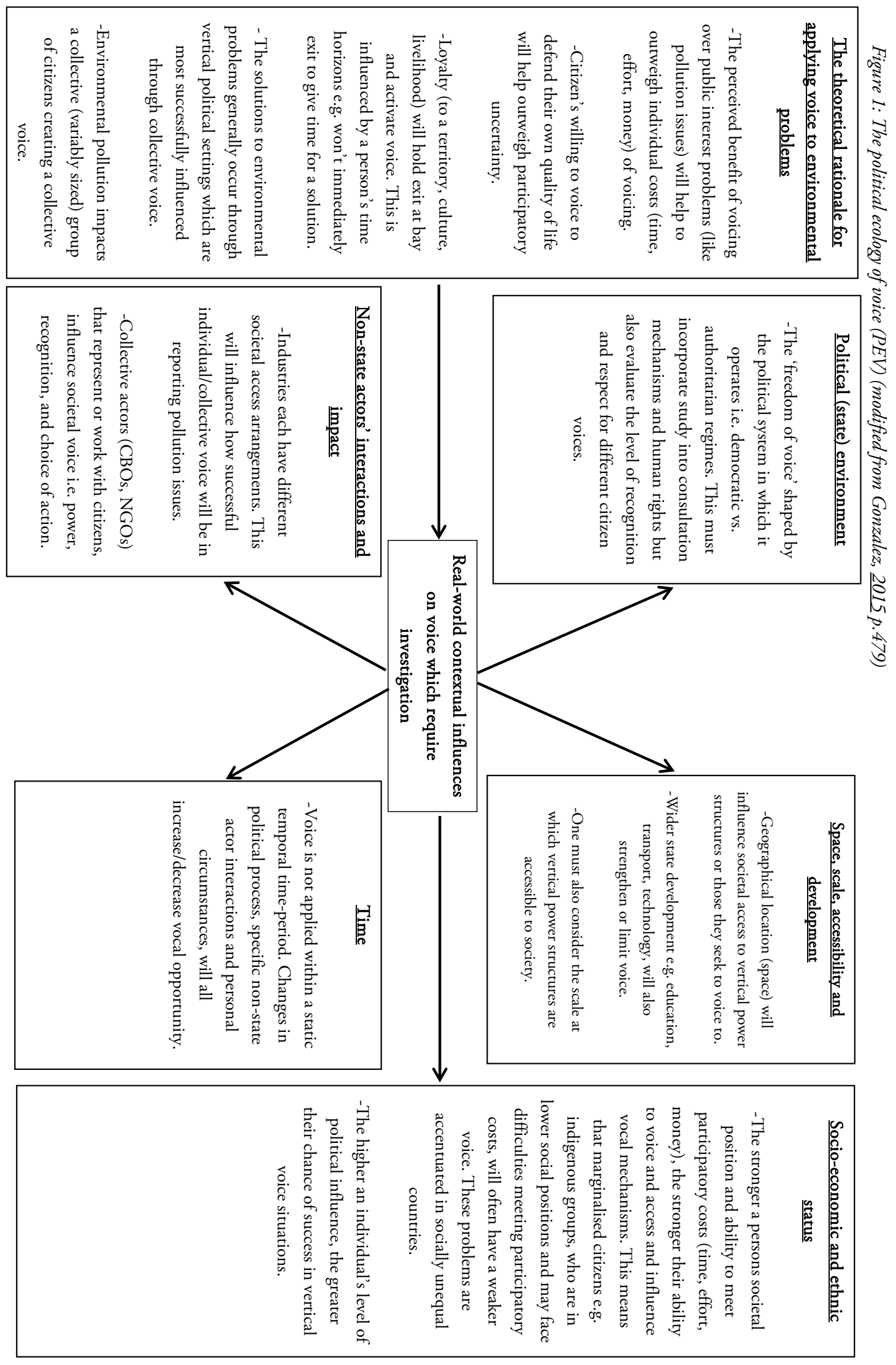

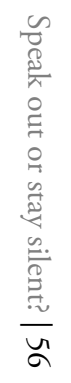




\section{Methodology and case study information}

Field work was conducted in 2015 for three and a half months in Peru's Loreto Region. This is the largest region in Peru and is geographically more extensive than Germany. It has a population of over 1 million people, 45 per cent of whom reside in the regional capital Iquitos. The remainder dwell in over 2,000 smaller, remoter river-edge communities (Brierely et al., 2014). Peru's on-shore oil operation is heavily concentrated on the Loreto Region which has been predominantly exploiting oil from two Blocks, 8 and 1AB/192 since 1969 and 1971 respectively. In 2014, these two Blocks accounted for 39.2 per cent of Peru's national oil production highlighting their significance (Orta-Martinez et al., 2018). These oil Blocks, alongside the North Peruvian pipeline, which transports crude oil from Loreto to the refineries on the Pacific coast, have been a major source of ongoing contamination. Wide research documents the significant environmental and health implications for indigenous communities resulting from oil production (Amnesty International, 2017; O'Callaghan-Gordo et al., 2018; Rosell-Melé, 2018). Meanwhile, the pipeline, built in the 1970s and operated by the state-run company Petroperu, is in a chronic state of disrepair and has been the cause of numerous oil spills (Photo 1). In 2016 alone, seven oil spills occurred, which led to an estimated 10,000 barrels to be spilt (Law in Action, 2017) and the closure of the pipeline until September 2017. Oil spills continue to plague the pipeline, including a recent 8,000-barrel spill which Petroperu attributed to vandalism (Cespades, 2018). 


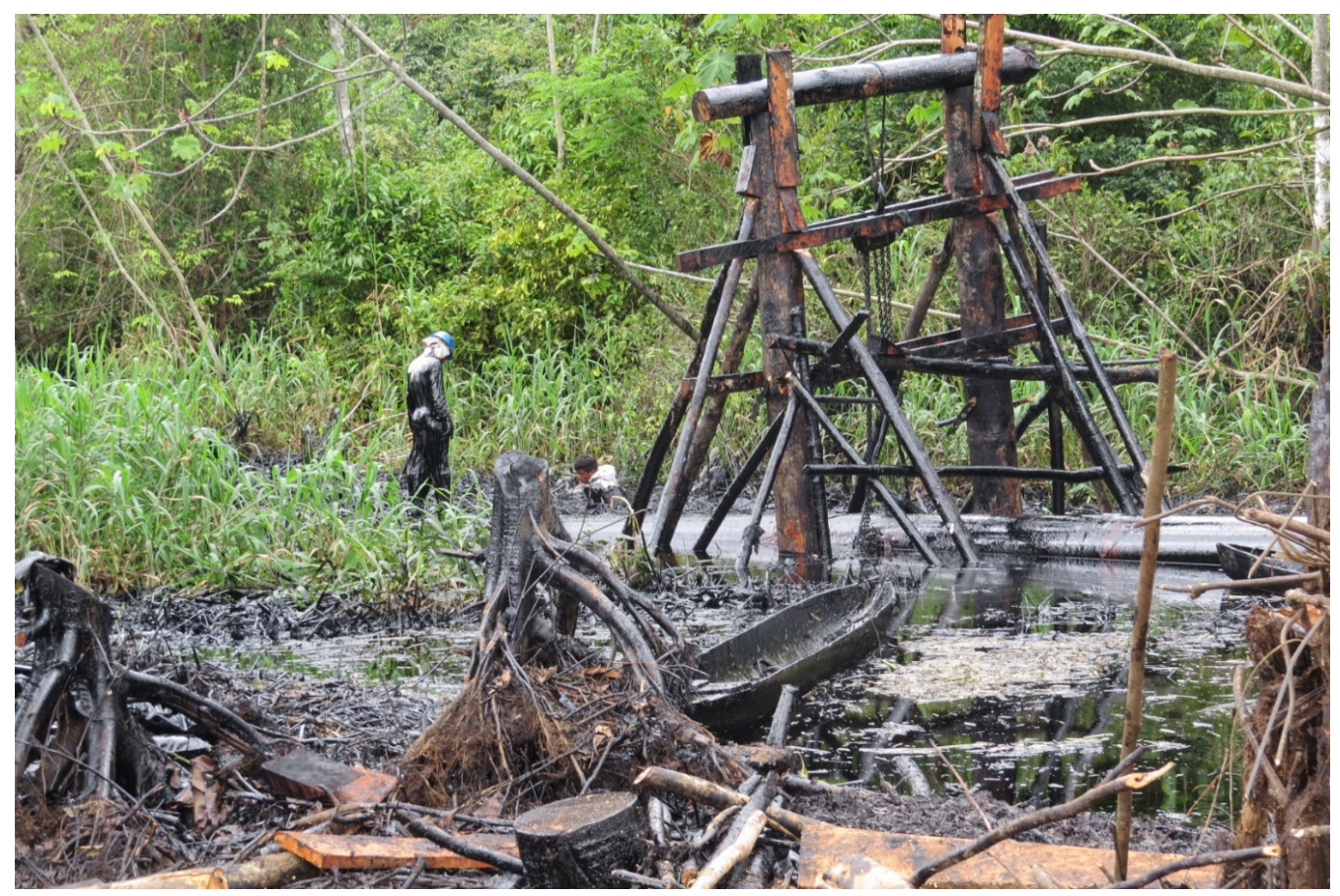

Photo 1: An indication of the pipeline's chronic state of disrepair and the impact that the Cuninico oil spill has had on the surrounding environment (Photo given to me by a Cuninico resident who himself received it from a Petroperu worker and used with their permission, June 2014).

This paper focuses on Cuninico, one of two case study communities explored in my $\mathrm{PhD}$, and their relationship with the state-run company Petroperu. Cuninico is home to roughly 500 indigenous Cocama (also spelt Kokáma) located on the banks of the River Marañón in Urarinas district, Loreto province, situated roughly 11 hours away by speed boat from Iquitos. In June 2014, the village were affected by a roughly 2,000-barrel spill from the North Peruvian pipeline, which burst into its dredged floatation channel before polluting the Cuninico, Marañón and wider river systems.

Data were obtained through semi-structured anonymised interviews, supported by interview participant observation (Elwood and Martin, 2000). The interviews took place with Cuninico residents as well as other relevant people such as human-rights defenders, journalists and community-based and non-governmental representatives. Despite my best efforts, no current oil industry representatives from Petroperu were willing to be interviewed. The interviews were conducted through an interview guide and with the aid of a paid local interpreter. Each participant was given a coded 
category based on their broad professional occupation, ethnicity, geographical location and number of the organisation and interviewee (see Appendix 1). A Google internet search enabled me to initially contact several community gatekeepers who could provide access to potential case study sites. Altogether, 110 interviews were conducted with 105 interviewees. 29 interviews took place with Cuninico residents. Interview transcripts were produced by a team of paid UK translators and analysed through QSR Nvivo software via a coding process (Taylor and Bogdan, 1998), supported by a loose research storyline based upon the PEV theoretical framework.

\section{Contextualising meaningful participation}

To understand this study of meaningful participation between Petroperu and Cuninico fully, one must acknowledge the wider PEV context (see Figure 1) in which it operates. There are several key parts which are important to summarise. The first is the political or state environment which has an integral impact on the "freedom of voice" and the ability of citizens and other stakeholders to vocalise concerns without fear of reprisal. Broadly, speaking, democratic countries offer a safer freedom of voice in comparison to authoritarian countries. In Peru, the military's significant role in shaping national politics in the nineteenth and twentieth centuries has transformed into a consolidation of democratic norms and principles since the election of Alan Garcia in 2001. This is evident in Peru's 1993 constitution, which sets out various civil rights and responsibilities under Title 1, Chapter 1, Article 2, which in turn are protected and enforced through the Office of Ombudsman. At a regional level, Peru is also a member of the Organisation of American States and accompanying mechanisms. ${ }^{1}$ Internationally, it has also ratified various relevant treaties including the International Covenant on Civil and Political Rights (ICCPR) (ratified 1978), Convention on the Rights of the Child (ratified 1990) and the ILO's Indigenous and Tribal People's Convention, 1989 (ILO Convention 169) (ratified 1994) (Gonzalez, $2018 b ; \underline{2018 c}$ ).

Consequently, one would expect Peru to have a strong freedom of voice. However, when one contextualises the focus onto the freedom of voice surrounding natural resource exploitation, a far suppressive and dangerous political environment is evident. This situation is primarily driven by the state's advancement and protection of a highly racialised, neoliberal agenda, which seeks to exploit natural resources in 
the Amazon and wider Peru at the deliberate expense and dispossession of ingenious people (de la Cadena, 2001; Gonzalez, 2018b). This agenda's impact on meaningful participation becomes evident. A 2017 visit by the United Nations Working Group on Business and Human Rights concluded that a lack of meaningful participation and consultation with communities affected by business operations is another main source of social conflict' (Office of the High Commissioner for Human Rights, 2017). Despite Peru's law of prior consultation and environmental impact assessments mechanisms, local people are denied the opportunity to provide free, prior and informed consent to development projects, an issue also evident in other Latin American countries (Schilling-Vacaflor, 2016). Meanwhile, opponents of this agenda are delegitimised and attacked by the state through draconian surveillance, judicial harassment and physical violence (Latin American Andean Report, 2010; Front Line Defenders, 2014), a situation contributing to ongoing civil society deaths (Global Witness, 2018).

The pursuit of this agenda and the suppression of critical societal voices is also evident when one considers rural Loreton societal access to environmental justice through the state i.e. through legal or judicial mechanisms, and the accountability of economic actors for pollution. A 2019 PEV study of this issue found that the state is notably 'absent' from Loreto's rural communities where civil infrastructure such as legal, educational and medical facilities are sparse and often non-existent and accessibility to the state through river transport difficult (Gonzalez, 2019a). The national and regional government have little interest in providing this civil development, instead offering "token gestures [such as tin roofs] that don't really affect the way the whole economy operates in Loreto" (NGO1R1) or equally, disrupt extractive development. This situation is exacerbated by rural poverty where average income is often less than $\$ 1$ a day (Brierley et al., 2014) making boat trips to the regional capital too expensive. Meanwhile, discrimination also means that elected political representative have little interest in visiting or communicating with indigenous communities, weakening their trust in the state and forcing them to rely on informal governance networks e.g. volunteer police or judges, that exacerbate rather than improve state access for rural communities.

Consequently, for indigenous communities like Cuninico, accessing state-based environmental justice is not only challenging but sees the state unwilling to support or recognise these societal claims. Indigenous Peruvian people remain excluded to environmental citizenship rights. This "shadow environmental citizenship" leaves 
communities reliant on non-state actors like non-governmental organisations or their indigenous federations and fuels more radical or unorthodox voice actions such as oil pipeline blockades by people seeking access to or recognition of environmental injustice (Gonzalez, 2019a).

\section{Inaccessible and suppressive; the reality of Cuninico's meaningful participation with Petroperu}

As noted in the contextual outline, Peru has been criticised for its lack of meaningful participation and it is no surprise to find that its state-owned oil company is failing to adhere to this concept. Prior to the 2014 spills, Cuninico interviewees confirmed that Petroperu had never visited the community. "We don't know them" (IRC16), leading to an unbalanced "contradictory" relationship (IRC17). This is surprising given that the North Peruvian pipeline, constructed almost two decades after the founding of Cuninico in 1959, passes in relative proximity to the community. Moreover, Petroperu personnel are located at the pipeline's pumping station no. 1 in San José de Saramuro, only three hours away from Cuninico by speedboat, a relatively short travel time given Loreto's vast size.

This testimony indicates a complete absence of meaningful participation or dialogue of any kind between Cuninico and Petroperu which would have significant repercussions in crisis situations. In the case of the 2014 spill, the community were unsure who operated the pipeline or the procedure to follow. Quite by accident, they were able to contact the company via a telephone number located on the back of a Petroperu sponsored school textbook given to the Ministry of Education for distribution in Loreto. It is evident that were it not for the spill, Petroperu would have continued to remain disengaged from Cuninico. Further analysis of the event indicates that this was built on a wider platform of exploitation and discrimination that echoes the country's historic 'silent racism' (de la Cadena, 2001).

Throughout the approximately four-month remediation period, Cuninico interviewees confirmed that Petroperu engineers refused to provide the community with any information about the spill such as water quality results, how the spill could affect residents, a timeframe for completion or the diagnosis and treatment of sick oil labourers, described shortly (Gonzalez, 2018a). The community leader was deliberately misinformed that the oil water near Cuninico was in fact "vegetable oil" (IRC2). However, my photographic evidence of oil at three different sites along the 
River Cuninico, adjacent to the village, disputes this claim (see Photo 2). Despite the impact on the village's food and water, the company provided Cuninico with only limited provisions for five months (August-December 2015), which left community members eating contaminated fish "out of necessity" (IRC7) and drinking boiled rain or river water. Access to clean water remains an ongoing issue (Fraser, 2016).

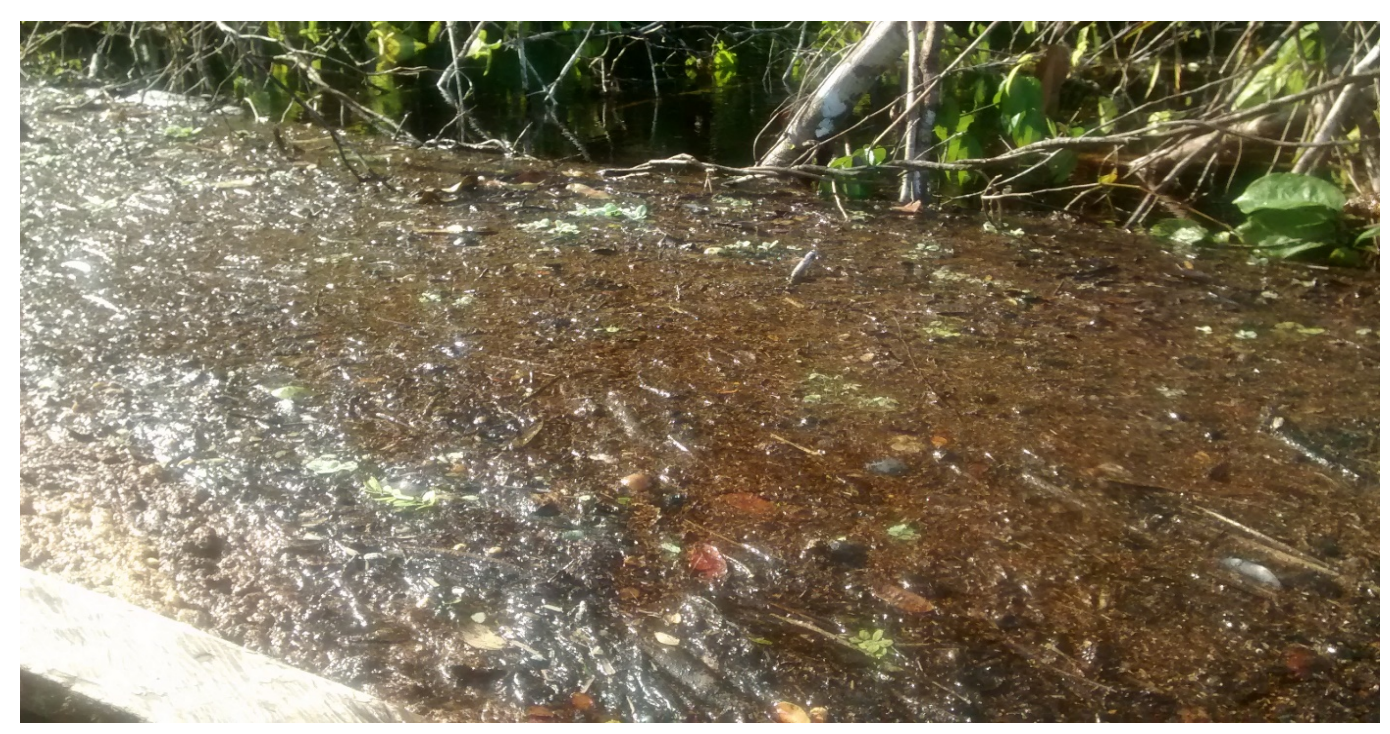

Photo 2: A close-up photograph taken in May 2015, of one of three oil sites on the River Cuninico, approximately 30-minutes up-river from the village (Photo taken by researcher, May 2015).

The greatest indicator of mistreatment was the company's employment of approximately 150 Cocama in remediation work. On a wage of 150 soles a day, equivalent to $\$ 45$ in today's currency, a group of these indigenous community members had:

"to try to lift the pipeline, we had to immerse in that water without any protection ... under the instruction of engineers, they told us that we had to try to reach it, so we did immerse there without any clothing, only underwear and it was full of crude oil, it was thick" (IRC13; see Photo 3).

Other residents, on a cheaper wage of 80 soles $(\$ 24)$, were tasked with scooping oil into buckets using a funnel, which often spilt oil onto their bodies as the thin white protective overalls they were given offered inadequate protection and routinely 
ripped. Petroperu subsequently provided them with gasoline to wash it off their bodies. Interviewed residents also alleged that the company knowingly employed four under-age children aged between 15 and 17 years old in the remediation work. According to one of the minors:

"I started working gathering the rubbish. But at the end that wasn't what I was doing. I was supposed to gather all the rubbish, but at the end I was working with the oil, getting it out of the waterfalls.... I sank my body up to the waist, half my body I sank to pick that up and give it to my other partners to fill up the barrel" (IRC100).

Unsurprisingly, resident workers reported significant health problems including allergic reactions and boils, numbness and weakness in their bodies, stomach problems, sore and locked joints, fevers, pain and blood from urinating and breathing difficulties (Gonzalez, 2018a).

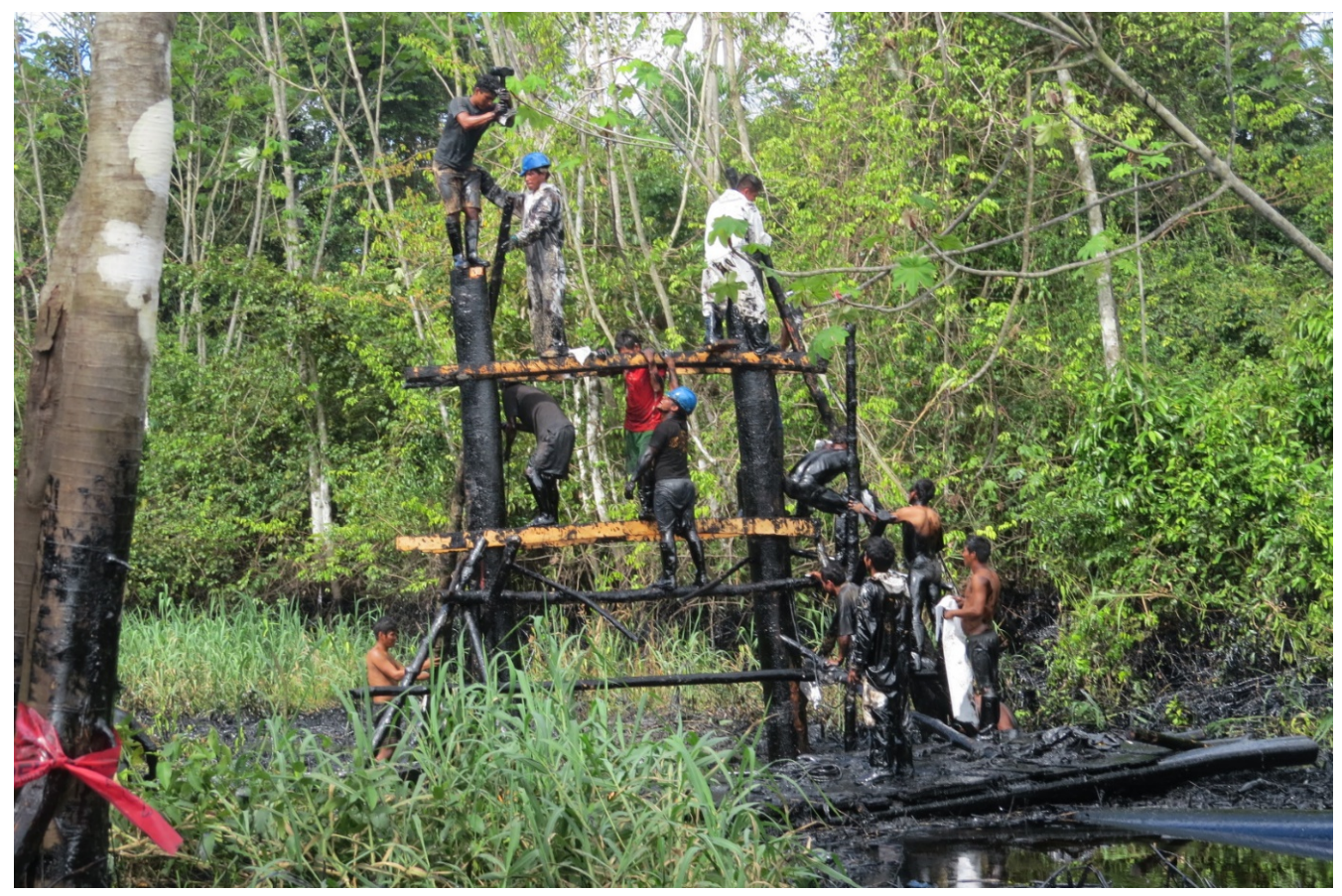

Photo 3: Cuninico residents inserting removing one of the wooden timber frames the supports the North Peruvian pipeline. The absence of heavy lifting equipment and limited white protective overalls are clearly visible (Photo given to me by a Cuninico resident who himself received it from a Petroperu worker and used with their permission, June 2014). 
Speak out or stay silent? | 64

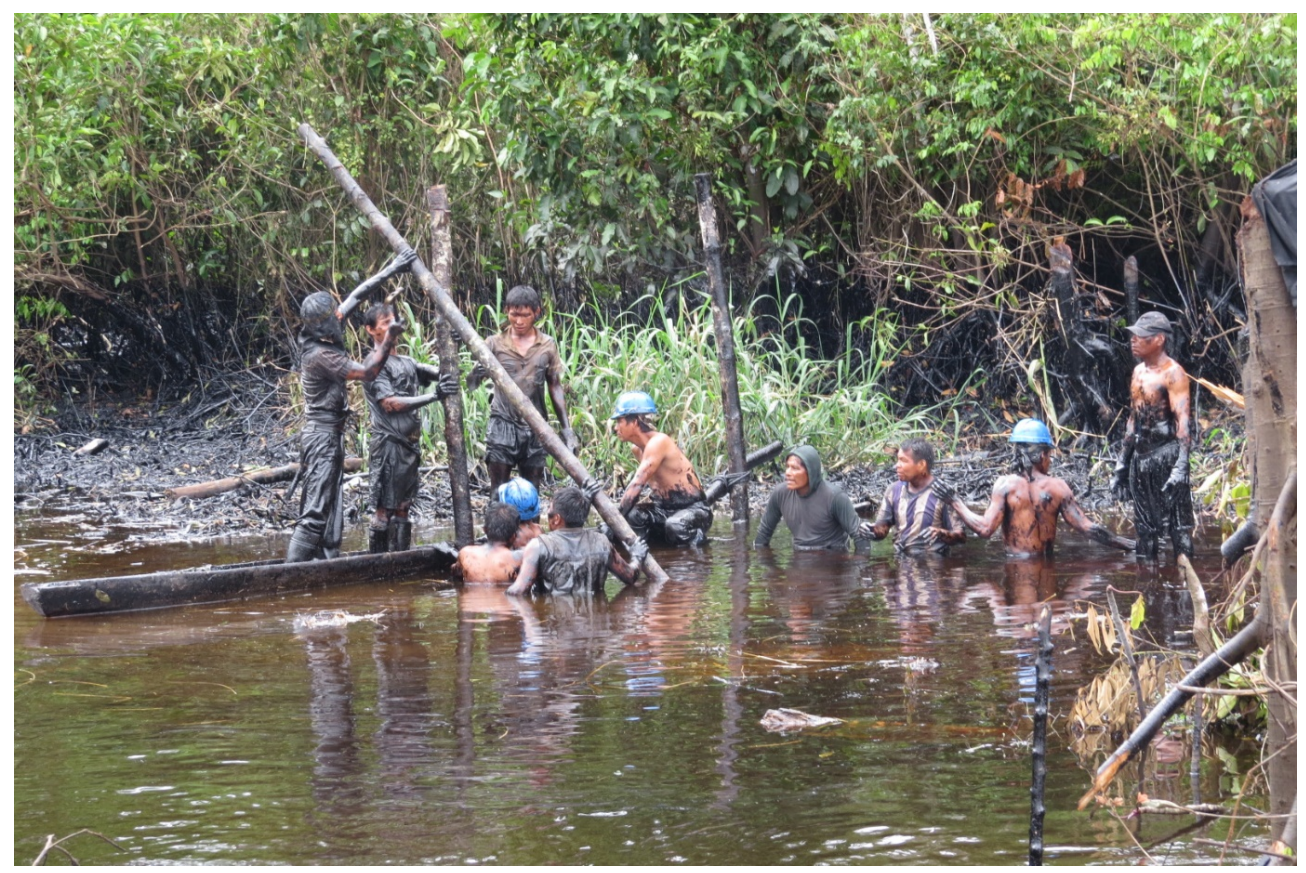

Photo 4: Cuninico interviewees allege that four under-age children, some of whom are in this photograph, were knowingly employed in the exploitative remediation work (Photo given to me by a Cuninico resident who himself received it from a Petroperu worker and used with their permission, June 2014).

However, it became clear that this offer of employment was conditional based on community silence. According to Cuninico's Catholic priest, Petroperu sought to "negotiate silently ... without anyone's knowledge" in order to conclude a deal to "bide everything" (CBO4R3) and prevent wider knowledge about the spill. Residents were initially told to remain silent about the spill or lose their employment opportunity. Given their economic poverty, they took these blunt threats "seriously" (IRC7) which left them, as Petroperu hoped, feeling "scared," "afraid to talk ... [and] silent [with] ... only three or four people ... who spoke up and defended the village" (IRC7)' (Gonzalez 2018a, p.326). The establishment of this 'climate of fear' continued through further threats made during remediation work (Gonzalez, 2018a). Oil worker interviewees recounted that Petroperu told them to not criticise their working practices or question the company in any way. One interviewee, IRC13, was fired for questioning the company about the contamination. Given these circumstances, 
people "didn't say a word" (IRC7) and "kept quiet" about their employment conditions and "endur[ed] it" (IRC6). The climate of fear was only broken by the strong, resolute resolve of the community leader and their trusted links to the Catholic Church. These trusted links had been built through their engagement with two parish priests, who had worked in Cuninico for over thirty years, providing educational and civil development support. Their involvement, supported by their partners including Cuninico's' indigenous federation, enabled the village's story to be told and begin the ongoing process of holding Petroperu accountable for the pollution event and exploitative employment practices. Crucially, they have provided access to transnational legal justice that transcends the challenge of gaining environmental justice in Peru (Peru Support Group 2016; 2017).

At the time of my interviews in May 2015, residents reported that Petroperu had failed to communicate with the whole community since leaving Cuninico in December 2014, instead meeting the community leader intermittingly at pumping station no.1 at José de Saramuro. Meanwhile, recent research by Transparency International indicates that Cuninico residents continue to suffer from adverse health issues including cramps, stomach ache, colic, allergies and miscarriages in women, symptoms indicative of heavy metal poisoning (Amnesty International, 2017).

\section{Conclusion; speaking up or staying silent in Peru's Loreto Region}

Through PEV, this article has briefly charted the reality of meaningful participation in Peru's Loreto Region, focusing on Petroperu and their relationship with Cuninico. It has shown that there is no semblance of ongoing meaningful participation or any form of dialogue, which significantly reduces the community's ability to report and hold the company accountable for pollution issues. This is exacerbated by Petroperu's deliberate efforts to silence the village by preying upon their economic poverty and dependency on the company for work. Whilst this climate of fear was broken by strong resolute leadership and connections to trusted non-state actors, this is not always the case. Cuninico's Catholic priest described how one other community, José de Saramuro, suffering from an oil spill a week earlier than Cuninico, decided to not speak out for fear of losing their manual labour jobs at pumping station no. 1 (Gonzalez, 2018a). The struggle between speaking out over pollution, injustice and exploitation and economic necessity and wider survival is ever present and ongoing. 
Speak out or stay silent? | 66

This situation is exacerbated by the wider challenges presented within the PEV environment. Not only is there a restrictive freedom of voice but rural communities are affected by shadow environmental citizenship exacerbating the use of radical acts or necessitating the support of non-state actors. Both of these actions can present complications. Radical acts can enable injustice issues to be noticed and achieve resolution. For example, Achuar mobilisations in Loreto helped lead to the Dorrissa Accords which stipulated the reinjection of produced water by Pluspetrol in Blocks 8 and $1 \mathrm{AB} / 192$ and rural civil development (Orta-Martinez et al., 2018). However, state failure to abide by these agreements (in this case the civil development objectives) causes a cyclical resumption of radical action by local people trying to hold them to account. Meanwhile, the reliance on community-based and nongovernmental organisations can improve meaningful participation through their support for community monitoring activities (Gonzalez, 2019b). The situation becomes more complex when communities seek environmental justice through nonstate actors. Different community-based and non-governmental organisations will each have their own ideas of what "justice" entails such as private financial agreements with extractive or legal action (Cultural Survival, 2015; BBC News, 2018). This leads to a multiplicity of environmental justice claims in Loreto which do little to equalise it or combat shadow environmental citizenship, particularly as non-state actors do not uniformly operate with every rural community (Gonzalez, 2019b).

Overall, in Loreto's PEV environment, the absence of meaningful participation by state-run Petroperu is symbolic of the wider political state's detachment and discrimination shown to indigenous citizens. Sadly, the reports of minors employed by Petroperu in 2016 remediation work (Davies, 2016) indicate that Cuninico's experiences are not unique and that the company has shown little interest in improving its operational practices away from the systematic abuse of indigenous people who will face a struggle between speaking out or staying silent.

\section{References}

Aaron, K. K. and Patrick, J. M. (2013) 'Corporate social responsibility patterns and conflicts in Nigeria’s oil-rich region,' International Area Studies Review, 16(4):341356. Available at: http://citeseerx.ist.psu.edu/viewdoc/download?doi=10.1.1.910.3864\&rep=rep1\&ty pe=pdf (Accessed 21 May 2019). 
Adams, D., Adams, K., Ullah, S. and Ullah, F. (2019) 'Globalisation, governance, accountability and the natural resource 'curse': implications for socio-economic growth of oil-rich developing countries,' Resources Policy, 61:128-140.

Ahlborg, H. and Nightingale, A. J. (2018) 'Theorising power in political ecology: the where of power in resource governance projects,' Journal of Political Ecology, 25:381. [Online]. Available at: https://journals.uair.arizona.edu/index.php/JPE/article/view/22804 (Accessed 24 June 2019).

Amnesty International (2017) A toxic state: violations of the right of health of indigenous peoples in Cuninico and Espinar, Peru. London. Available at: http://www.toxicstate.pe/cuninico-location/ (Accessed 20 May 2019).

Amnesty International (2018) Negligence in the Niger Delta: decoding Shell and Eni's poor record on spills. Available at: https://www.amnesty.org/en/documents/afr44/7970/2018/en/ (Accessed 21 May 2019).

Andrews, A. (2014) 'Downward accountability in unequal alliances: explaining NGO responses to Zapatista demands,' World Development, 54:99-113.

Arsel, M., Pellegrini, L., and Mena, C. F. (2019) 'Maria's paradox: oil extraction and the miosery of missing development alternatives in the Ecuadorian Amazon,' in Shaffer, P., Kanbur, R., and Sandbrook R. (eds.,) Immiserising growth: when growth fails the poor. Oxford: Oxford University Press.

Barrera-Hernández, L. (2016) 'Indigenous peoples and free, prior, and informed consent in Latin America,' in Barrera-Hernández, L., Barton, B., Godden, L., Lucas, A., and Ronne, A. (eds.,) Sharing the costs and benefits of energy and resource activity: legal change and impact on communities. Oxford: Oxford Scholarship Online, pp.123.

Barrett, P. M. (2014) Law of the jungle: the $\$ 19$ billion legal battle over oil in the rain forest and the lawyer who'd stop at nothing to win. New York: Penguin Random House.

BBC News (2018) Chevron wins Ecuador rainforest 'oil dumping' case. 8 September. Available at: https://www.bbc.co.uk/news/world-latin-america-45455984 (Accessed 10 April 2019). 
Speak out or stay silent? | 68

Bebbington, A. (2012) 'Underground political ecologies: the second annual lecture of the cultural and political ecology speciality group of the association of American geographers,' Geoforum, 43(6):1152-1162.

Bebbington, A. and Bebbington, D. H. (2011) 'An Andean Avatar: post-neoliberal and neoliberal strategies for securing the unobtainable,' New Political Economy, 16(1):131-145.

Bebbington, A. J. and Bury, J. F. (2009). 'Institutional challenges for mining and sustainability in Peru,' Proceedings of the National Academy of Sciences, 106(41):17296-17301.

Brierley, C. K., N. Suarez., G. Arora, and D. Graham. (2014) 'Healthcare access and health beliefs of the indigenous in remote Amazonian Peru,' The American Journal of Tropical Medicine and Hygiene, 90(1):180-183. Available at: https://www.ncbi.nlm.nih.gov/pmc/articles/PMC3886418/ (Accessed 21 May 2019).

Bryant, R. L. (2015) 'Reflecting on political ecology,' in Bryant, R. L. (ed.), The international handbook of political ecology (pp.14-24). Cheltenham: Edward Elgar Publishing Limited.

Byakagaba, P., Mugagga, F. and Nnakayima, D. (2019) 'The socio-economic and environmental implications of oil and gas exploration: perspectives at the micro level in the Albertine region of Uganda,' The Extractive Industries and Society, 6(2):358366.

Cespedes, T. (2018) 'Vandals cause 8,000 barrels of oil to spill in Peruvian Amazon,' Reuters, 28 November. Available at: https://www.reuters.com/article/us-peru-oilspill/vandals-cause-8000-barrels-of-oil-to-spill-in-peruvian-amazon-

idUSKCN1NX2LK (Accessed 20 May 2019).

Clapp, R. A. (2004) 'Wilderness ethics and political ecology: remapping the Great Bear Rainforest,' Political Geography, 23(7):839-862.

Cook, N. J., Wright, G. D. and Andersson, K. P. (2017) 'Local politics of forest governance: why NGO support can reduce local government responsiveness,' World Development, 92:203-214.

Crisp, R., McCarthy, L., Parr, S. and Pearson, S. (2016) Community-led approaches to reducing poverty in neighbourhoods: a review of evidence and practice. Centre for 
Regional Economic and Social Research, Sheffield Hallam University and Joseph Rowntree Foundation. Available at: https://www4.shu.ac.uk/research/cresr/sites/shu.ac.uk/files/community-ledapproaches-to-reducing-poverty-in-neighbourhoods.pdf (Accessed 21 May 2019).

Constantino, P. D. A. L., Carlos, H. S. A., Ramalho, E. E., Rostant, L., Marinelli, C. E., Teles, D., Fonseca-Junior, S. F., Fernandes, R. B., and Valsecchi, J. (2012) 'Empowering local people through community-based resource monitoring: a comparison of Brazil and Namibia,' Ecology \& Society, 17(4:22. Available at: https://www.ecologyandsociety.org/vol17/iss4/art22/ (Accessed 12 November 2019).

Costa, D. C., Pereira, H. S., Marchandm G. A. E. L., and Silva, S. C. P. (2018) 'Challenges of participatory community monitoring of biodiversity in protected areas in Brazilian Amazon,' Diversity, 10(3). Available at: https://www.mdpi.com/14242818/10/3/61 (Accessed 11 November 2019).

Cultural Survival. 2015. Justice is served: Achuar celebrate victory over Occidental Petroleum. Cultural Survival Quarterly Magazine, CSQ issue: 39-2 standing strong from the ground. Available at: https://www.culturalsurvival.org/publications/cultural-survival-quarterly/justiceserved-achuar-celebrate-victory-over-occidental (Accessed 27 March 2019).

Davies, W. (2016) 'Indigenous community in Peru suffers after oil spill,' BBC News, 15 March. Available at: https://www.bbc.co.uk/news/world-latin-america-35803496 (Accessed 20 May 2019).

de la Cadena, M. (2001) 'The racial politics of culture and silent racism in Peru,' conference paper presented at Racism and Public Policy, United Nations Research Institute for Sustainable Development, Durban, South Africa, 3-5 September. Available at: http://www.unrisd.org/80256B3C005BCCF9/httpNetITFramePDF?ReadForm\&p arentunid=EE7EB1E30A96C11F80256B6D00578643\&parentdoctype=paper\&ne titpath $=80256 \mathrm{~B} 3 \mathrm{C} 005 \mathrm{BCCF} /(\mathrm{httpAuxPages}) / \mathrm{EE} 7 \mathrm{~EB} 1 \mathrm{E} 30 \mathrm{~A} 96 \mathrm{C} 11 \mathrm{~F} 80256 \mathrm{~B} 6 \mathrm{D} 0$ 0578643/\$file/dcadena.pdf (Accessed 21 May 2019).

Doro, E. and Kufakurinani, U. (2018) 'Resource curse or governance deficit? The role of parliament in Uganda's oil and Zimbabwe's diamonds,' Journal of Southern African Studies, 44(1):43-57. 
Speak out or stay silent? | 70

Elwood, S. A. and Martin, D. G. (2000) “"Placing” interviews: location and scales of power in qualitative research,' The Professional Geographer,52(4):649-657.

Flemmer R. and Schilling-Vacaflor, A. (2015) 'Unfulfilled promises of the consultation approach: the limits to effective indigenous participation in Bolivia's and Peru's extractive industries,' Third World Quarterly, 37(1):172-188.

Fraser, B. (2016) 'Cuninico: the fight for clean water continues,' Mongabay, 19 December. Available at: https://news.mongabay.com/2016/12/cuninico-thefight-for-clean-water-continues/ (Accessed 20 May 2019).

Front Line Defenders (FLD) (2014) Environmental rights defenders at risk in Peru. Available at: https://www.frontlinedefenders.org/en/statementreport/environmental-rights-defenders-risk-peru (Available at 18 October 2019).

Gehab, K. and Suhardiman, D. (2019) 'The political ecology of hydropower in the Mekong River Basin,' Current Opinion in Environmental Sustainability, 37:8-13.

Global Witness (2018) At what cost? Irresponsible business and the murder of land and environmental defenders in 2017. Available at: https://www.globalwitness.org/en/campaigns/environmental-activists/at-what-cost/ (Accessed 27 March 2019).

Gonzalez, A. (2015) 'The political ecology of voice (PEV); an innovative approach to examining environmental pollution and the accountability of economic actors,' Journal of Political Ecology, 22:466-485 Available at: https://journals.uair.arizona.edu/index.php/JPE/article/view/21119 (Accessed 14 November 2019).

Gonzalez, A. (2016a) 'The land of black gold, corruption, poverty and sabotage: overcoming the Niger Delta's problems through the establishment of a Nigerian nonrenewable revenue special fund (NNRSF),' Cogent Social Sciences, 2:1126423. Available at: https://www.cogentoa.com/article/10.1080/23311886.2015.1126423 (Accessed 21 May 2019).

Gonzalez, A. (2016b) 'Poverty, oil and corruption: the need for a quad sector development partnership (QSDP) in Nigeria's Niger Delta,' Development Policy Review, 34(4):509-538. Available at: https://www.researchgate.net/publication/303888145 Poverty oil and corruption the need for a Quad- 
Sector Development Partnership QSDP in Nigeria's Niger Delta (Accessed 21 May 2019).

Gonzalez, A. (2018a) 'Control, fear and suppression: a political ecology of voice (PEV) study into resource extraction industry-community engagement in Peru's Loreto Region,' The Extractive Industries \& Society, 5(3):319-329.

Gonzalez, A. (2018b) "'A salute to the bandido": a political ecology of voice exploration into Peru's freedom of voice surrounding hydrocarbon development,' Society \& Natural Resources, 31(6):649-665.

Gonzalez, A. (2018c) 'How Peru excludes indigenous voices in its quest to develop the Amazon,' The Conversation, 8 February, UK Edition. Available at: https://theconversation.com/how-peru-excludes-indigenous-voices-in-its-quest-todevelop-the-amazon-91449 (Accessed 20 May 2019).

Gonzalez, A. (2019a) 'Making "a racket" but does anybody care? A study of environmental justice through the political ecology of voice,' Geoforum, 102:142156.

Gonzalez, A. (2019b) Justice for whom? A political ecology of voice investigation into non-state actor impact on societal environmental justice. Political Geography (revised and resubmitted end of October 2019).

Greenberg, J. B. and Park, T. K. (1994) 'Political ecology,' Journal of Political Ecology, $1(1): 1$. Available at: https://journals.uair.arizona.edu/index.php/JPE/issue/view/1435 (Accessed 20 May 2019).

Groves, C. (2015) 'The bomb in my backyard, the serpent in my house: environmental justice, risk, and the colonialisation of attachment,' Environmental Politics, 24(6):853- 873.

Harriss, L. M. and Alatout, S. (2010) 'Negotiating hydro-scales, forging states: comparison of the Tigris/Euphrates and Jordan River Basins,' Political Geography, 29(3):148-156.

Hirschman, A. O. (1970) Exit, voice, and loyalty: responses to decline in firms, organisations and states. Cambridge, Massachusetts: Harvard University Press.

Hirschman, A. O. (1978) 'Exit, voice, and the state,' World Politics, 31(1):90-107. 
Speak out or stay silent? | 72

Hirschman, A. O. (1981) Essays in trespassing: economics to politics and beyond. Cambridge, UK: Cambridge University Press.

Hirschman, A. O. (1982) Shifting involvements: private interest and public action. Oxford: Martin Robertson.

Hirschman, A. O. (1995) A propensity to self-subversion. Cambridge, Massachusetts: Harvard University Press.

Hoelscher, K. and Rustad, S. A. (2019) 'CSR and social conflict in the Brazilian extractive sector,' Conflict, Security \& Development, 19(1):99-119. Available at: https://www.tandfonline.com/doi/abs/10.1080/14678802.2019.1561633 (Accessed 21 May 2019).

Holck, M, H. (2008) Participatory forest monitoring: an assessment of the accuracy of simple cost-effective methods,' Biodiversity and Conservation, 17(8):2023-2036.

Ingalls, M. L and Stedman, R. C. (2016) 'The power problematic: exploring the uncertain terrains of political ecology and the resilience framework,' Ecology and Society, 21(1):6. Available at: https://www.ecologyandsociety.org/vol21/iss1/art6/ (Accessed 20 May 2019).

Karpouzoglou, T., Marshall, F. and Mehta, L. (2018) 'Towards a peri-urban political ecology of water quality decline,' Land Use Policy, 70:485-493.

Kemp, D. and Owen, J. R. (2013) 'Community relations and mining: core to business but not "core business", Resources Policy, 38(4):523-531.

Latin American Andean Group Report (2010) Latin American regional report Andean group. Available at: http://latinnews.com/media/k2/pdf/CVC2.pdf (Accessed 18 October 2019).

Law in Action (2017) 'How many oil barrels have spilled in the Amazon,' 2 October. Available at: http://www.alphabetics.info/international/how-many-oil-barrels-havespilled-in-the-amazon/ (Accessed 20 May 2019).

Lundgren, C. J., Thomas, A. H., and York, R. C. (2013) Boom, bust, or prosperity? Managing sub-Saharan Africa's natural resource wealth. Washington, USA: International Monetary Fund Available at: https://www.imf.org/external/pubs/ft/dp/2013/dp1302.pdf (Accessed 12 November 2019). 
Mehlum, H., K. Moene, and R. Torvik (2006) 'Institutions and the resource curse,' The Economic Journal, 116(508):1-20.

Natural Resource Governance Institute (2015) 'The resource curse: the political and economic challenges of natural resource wealth,' March. Available at: https://resourcegovernance.org/sites/default/files/nrgi Resource-Curse.pdf (Accessed 21 May 2019).

Obida, C. B., Blackburn, G. A., Whyatt, J. D. and Semple, K. T. (2018) 'Quantifying the exposure of humans and the environment to oil pollution in the Niger Delta using advanced geostatistical techniques,' Environment International, 111:32-42.

O’Callaghan-Gordo, C., Flores, J. A., Lizárraga, P., Okamoto, T., Papoulias, D. M., Barclay, F., Orta-Martinez, M., Kogevinas, M. and Astee, J. (2018) 'Oil extraction in the Amazon basin and exposure to metals in indigenous population,' Environmental Research, 162:226-230.

O’Donnell, G. (1986) 'On the fruitful convergences of Hirschman's exit, voice, and loyalty and shifting involvements: reflections from the recent Argentine experience,' in Foxley, A., McPherson, M. S., O’Donnell, G. A. and Hirschman, A. O. (eds.) Development, democracy, and the art of trespassing: essays in honour of Albert $O$. Hirschman (pp.249-268). Notre Dame, Indiana: University of Notre Dame Press.

OECD (2015) Due diligence guidance for meaningful stakeholder engagement in the extractive sector. Available at: https://www.oecd.org/daf/inv/mne/OECD-GuidanceExtractives-Sector-Stakeholder-Engagement.pdf (Accessed 21 May 2019).

Office of the High Commissioner for Human Rights (OHCHR) (2017) 'Statement at the end of visit to Peru by the United Nations working group on business and human rights. Available at: https://www.ohchr.org/EN/NewsEvents/Pages/DisplayNews.aspx?NewsID=21888 $\underline{\text { LangID }=\mathrm{E}}$ (Accessed 12 November 2019).

Okonta, I. and Douglas, O. (2003) Where vultures feast: Shell, human rights and oil in the Niger Delta. London: Verso.

Orta-Martinez, M., L. Pellegrini., and M. Arsel. (2018) “"The squeaky wheel gets the grease"? The conflict imperative and the slow fight against environmental injustice in northern Peruvian Amazon,' Ecology and Society:23(7):7. Available at: 
Speak out or stay silent? | 74

https://www.ecologyandsociety.org/vol23/iss3/art7/\#theconflicti14 (Accessed 20 May 2019).

Perreault, T. (2003) 'Changing places: transnational networks, ethnic politics, and community development in the Ecuadorian Amazon,' Political Geography, 22(1):6188.

Peru Support Group (2016) 'Petroperu admits to jungle spill,' 19 June. Available at: http://www.perusupportgroup.org.uk/news-article-1129.html (Accessed 20 May 2019).

Peru Support Group (2017) 'IACHR grants precautionary measures over Loreto oil spills,' 10 December. Available at: http://www.perusupportgroup.org.uk/newsarticle-1509.html (Accessed 20 May 2019).

Picciotto, R. (2015) 'Hirschman's ideas as evaluation tools,' Journal of MultiDisciplinary Evaluation, 11(24):1-11. Available at: http://journals.sfu.ca/jmde/index.php/jmde 1/article/view/416 (Accessed 21 May 2019).

Ramana, M. V. (2013) 'Nuclear policy responses to Fukushima: exit, voice, and loyalty,' Bulletin of the Atomic Scientists, 69(2):66-76.

Ravnborg, H, M. and Gomez, L. I. (2015) 'The importance of inequality for natural resource governance: evidence from two Nicaraguan territories,' World Development, 73:72-84.

Rosell-Melé, A., Moraleda-Cibrián, N., Cartró-Sabaté, M., Colomer-Ventura, F., Mayor, P. and Orta-Martínezm M. (2018) 'Oil pollution in soils and sediments from the Northern Peruvian Amazon,' Science of the Total Environment, 610-611:10101019.

Saffari S. (2016) 'Can the subaltern be heard? Knowledge production, reproduction, and responsibility in international development,' Transcience, 7(1):36-46. Available at: https://www2.hu-berlin.de/transcience/vol7 no1 36 46.pdf (Accessed 21 May 2019).

Schilling-Vacaflor, A. (2016) 'Who controls the territory and the resources? Free, prior and informed consent (FPIC) as a contested human rights practice in Bolivia,' Third World Quarterly, 38(5):1058-1074. 
Spiegel, S. J. (2017) 'EIAs, power and political ecology: situating resource struggles and the techno-politics of small-scale mining,' Geoforum, 87:95-107.

Taarup-Esbensen, J. (2019) 'Managing risk through dependency: how do mining MNEs strategise to legitimise business continuity?' The Extractive Industries and Society, 6:489-497.

Taylor, S. J. and Bogdan, R. (1998) Introduction to qualitative research methods: a guidebook and resource. 3rd ed. New York: John Wiley \& Sons Incorporated.

Ulleberg. I. (2009) The role and impact of NGOs in capacity development. From replacing the state to reinvigorating education. United Nations Educational, Scientific and Cultural Organisation (UNESCO) and International Institute for Educational Planning. Available at: http://unesdoc.unesco.org/images/0018/001869/186980e.pdf (Accessed 20 May 2019).

Vijayakumar, G. (2018) 'Collective demands and secret codes: the multiple uses of "community" in "community mobilisation," World Development, 104:173-182.

White, N. D., Footer, M. E., Senior, K., van Dorp, M., Kiezebrink, V., Puraka, W. G. and Anzas, A. F. (2018) 'Blurring public and private security in Indonesia: corporate interests and human rights in a fragile environment,' Netherlands International Law Review, 65(2):217-252. Available at: https://link.springer.com/article/10.1007/s40802-018-0107-8 (Accessed 21 May 2019).

Willow, A. J. and Wylie, S. (2014) 'Politics, ecology, and the new anthropology of energy: exploring the emerging frontiers of hydraulic fracking,' Journal of Political Ecology, 21(1):222. [Online]. Available at: https://journals.uair.arizona.edu/index.php/JPE/article/view/21134 (Accessed 24 June 2019).

Wilson, E., S, Best., E, Blackmore and S. Ospanova. (2016) Meaningful community engagement in the extractive industries: stakeholder perspectives and research priorities. International Institute for Environment and Development, London. Available at: https://pubs.iied.org/pdfs/16047IIED.pdf (Accessed 20 May 2019).

Zuindeau, B. (2009) 'Responding to environmental risks: what can Albert Hirschman contribute?' Ecological Economics, 69(1):155-165. 
Speak out or stay silent? | 76

Appendix

Coding structure:

Cuninico

Coded as: Indigenous resident of Cuninico $\boldsymbol{n}$ (IRCn):

IRC1-IRC29

$\underline{\mathrm{CBO}}$

Coded as: $\mathrm{CBO} n$ representative $n(\mathrm{CBO} n \mathrm{R} n)$

- CBO4R3. Catholic Church Priest from The Apostolic Vicariate of Iquitos working in the Marañon River Basin. 